\title{
Correction to: The Early Development of Passive Treatment Systems for Mining-Influenced Water: A North American Perspective
}

\author{
Bob Kleinmann ${ }^{1}$ (i) $\cdot$ Jeff Skousen ${ }^{2}$ (i) $\cdot$ Tom Wildeman $^{3} \cdot$ Bob Hedin $^{4} \cdot$ Bob Nairn $^{5}$ (D) Jim Gusek ${ }^{6}$
}

Published online: 29 October 2021

(c) Springer-Verlag GmbH Germany, part of Springer Nature 2021

\section{Correction to: Mine Water and the Environment https://doi.org/10.1007/s10230-021-00817-8}

Unfortunately, several references were accidentally omitted from the list of references in the published version. We apologize for this oversight. The missing references are provided below.

In the text, the following references must be corrected:

Kleinmann \& Gerts (1986) $\rightarrow$ Kleinmann \& Gerts (1987)

Wieder et al. (1982) $\rightarrow$ Wieder \& Lang (1982)

Blowes et al. (1992) $\rightarrow$ Blowes et al. (1995)

In addition, in referring to volume-based sulfate reduction rate of $0.3 \mathrm{~mol} / \mathrm{m}^{3} /$ day, there was one instance where it was mistakenly referred to as $0.3 \mathrm{~mol} / \mathrm{day} / \mathrm{m}^{3}$. It should be 0.3 $\mathrm{mol} / \mathrm{m}^{3} /$ day in both instances.

\section{References}

Blowes DW, Ptacek CJ (1992) Geochemical remediation of groundwater by permeable reactive walls: removal of chromate by reaction with iron-bearing solids. Proc, $3^{\text {rd }}$ International Conf on Ground Water Quality Research, pp 214-216

Blowes DW, Ptacek CJ, Bain JG, Waybrant KR, Robertson WD (1995) Treatment of mine drainage water using in situ permeable reactive

The original article can be found online at https://doi.org/10.1007/ s10230-021-00817-8.
Bob Kleinmann
editor@MWEN.info
Jeff Skousen
jskousen@wvu.edu
Tom Wildeman
twildema@mines.edu
Bob Hedin
bhedin@hedinenv.com
Bob Nairn
nairn@ou.edu
Jim Gusek
jim.gusek@linkan.biz

walls. Proc, Sudbury '95. Mining and the Environment, CANMET, Ottawa, Ontario 3:979-987

Girts MA, Kleinmann RLP, Erickson PM (1987) Performance data on Typha and Sphagnum wetlands constructed to treat coal mine drainage. Proc, $8^{\text {th }}$ Annual Surface Mine Drainage Task Force Symp, available at: https://wvmdtaskforce.com/past-symposiumpapers/1987-symposium-papers/

Hedin RS, Dvorak DH, Gustafson SL, Hyman DM, McIntire PE, Nairn RW, Neupert RC, Woods AC, Edenborn HM (1991) Use of a constructed wetland for the treatment of acid mine drainage at the Friendship Hill National Historic Site, Fayette County, PA. Interagency Agreement \#4000-5-0010.

Kepler DA, McCleary EC (1997) Passive aluminum treatment success. Proc, $18^{\text {th }}$ West Virginia Surface Mine Drainage Task Force Symp, Morgantown, WV, available at: https://wvmdtaskforce. com/past-symposium-papers/1997-symposium-papers/

Kleinmann RLP (1985) Treatment of acid mine water by wetlands. Control of Acid Mine Drainage. Bur Mines Inf Circ IC 9027:48-52

Kleinmann RLP, Erickson PM, Girts MA, Hyman DM (1986) Workshop on passive treatment of mine drainage (unpublished)

Kleinmann RLP, Gerts MA (1987) Constructed wetlands for treatment of mine water-successes and failures. Proc, $8^{\text {th }}$ Annual National Abandoned Mine Lands Conf, published by Montana Dept. of State Lands, pp 67-73

Pearson FH, McDonnell AJ (1974) Chemical kinetics of neutralization of acidic water by crushed limestone. Proc. No. 18, Water Resources Problems Related to Mining, American Water Resources Assoc, Columbus, OH, pp 85-98

Pearson FH, McDonnell AJ (1975a) Use of crushed limestone to neutralize acid wastes. J Env Eng Div-ASCE 101:139-158

HDR, 2737 Beechwood Blvd, Pittsburgh, PA 15217, USA

2 Soils and Reclamation, Division of Plant and Soil Sciences, West Virginia University, Morgantown, WV 26506, USA

3 Department of Chemistry, Colorado School of Mines, Golden, CO 80401, USA

4 Hedin Environmental, 195 Castle Shannon Blvd, Pittsburgh, PA 15228, USA

5 Center for Restoration of Ecosystems and Watersheds, School of Civil Engineering and Environmental Science, The University of Oklahoma, Norman, OK 73019, USA

6 Linkan, 400 Corporate Circle, Suite H, Golden, Colorado 80401, USA 
Pearson FH, McDonnell AJ (1975b) Limestone barriers to neutralize acidic streams. J Env Eng Div-ASCE 101:425-440

Reynolds JS, Machemer SD, Wildeman TR, Updegraff DM, Cohen RR (1991) Determination of the rate of sulfide production in a constructed wetland receiving acid mine drainage. Proc, National Meeting of the American Soc of Surface Mining and Reclamation, pp 175-182

Skousen J (1991) Anoxic limestone drains for acid mine drainage treatment. Green Lands 21:30-35

Skousen J (1995) Douglas abandoned mine land project: description of an innovative acid mine drainage treatment system. Green Lands 25:29-38
Wieder RK, Lang GE (1982) Modification of acid mine drainage in a freshwater wetland. Proc, Symp on Wetlands of the Unglaciated Appalachian Region. West Virginia Univ, Morgantown, WV, pp 43-53

Ziemkiewicz PF, Skousen J, Lovett R (1994) Open limestone channels for treating acid mine drainage: a new look at an old idea. Green Lands 24:36-41

Ziemkiewicz PF, Skousen J, Brant D, Sterner P, Lovett R (1997) Acid mine drainage treatment with armored limestone in open limestone channels. J Environ Qual 26:560-569 